\title{
Bar Kohba i Drugi židovski ustanak
}

\section{Povijesni izvori: rimski, židovski, kršćanski i materijalni}

\author{
Boris Havel*
}

\begin{abstract}
Sažetak
Drugi je židovski ustanak protiv Rimljana (132.-135.) u mnogim vidovima historiografska nepoznanica: njegovi uzroci, tijek ratovanja, razina vojne uspješnosti kako ustanika tako i Rimljana, te opseg ustankom zahvaćena ozemlja ne mogu se sa sigurnošću utvrditi. Za razliku od Prvoga ustanka (66.-73.), o Drugom ne postoje opsežni izvori, nego raštrkani ulomci u tekstovima koji se njime bave usputno i sporadično. Arheološka otkrića iz druge polovice 20. stoljeća donijela su neke nove spoznaje, kao što je stvarno ime ustaničkoga vođe, te su potvrdila $i$ proširila dio ranijih saznanja. No brojni fragmenti još uvijek nedostaju kako bi se rekonstruirao tijek događaja koji spada među najvažnije za dugoročno oblikovanje židovskoga mesijanizma i percepciju suvremene židovske državnosti unutar religijske zajednice.
\end{abstract}

Ključne riječi: Bar Kohba, Judeja, kršćani, Židovi, Mesija, Hadrijan, Rimsko Carstvo

\section{Uvod}

Povijesni izvori o Drugom židovskom ustanku znatno su oskudniji od izvora koje, poglavito zahvaljujući Josipu Flaviju, postoje o ustanku od 66. do 73. godine, ${ }^{1}$ što je za posljedicu imao rimsko osvajanje Jeruzalema i uništenje Drugoga hrama. Ti se izvori ugrubo mogu podijeliti u četiri skupine: zabilješke rimskih povjesničara od kojih je najvažniji tekst Diona Kasija (150.-235.), židovski izvori iz Talmuda i midraša, ${ }^{2}$ izvori iz pera kršćanskih pisaca kao što su Justin, Euzebije, nepoznati

* Doc. dr. sc. Boris Havel, Fakultet političkih znanosti Sveučilišta u Zagrebu. Adresa: Lepušićeva 6, 10000 Zagreb, Hrvatska. E-adresa: boris.havel@fpzg.hr

1 Kao godinu okončanja Prvoga ustanka naveo sam 73. jer su Rimljani te godine zauzeli zadnje židovsko uporište Masadu. U mnogim se studijama kao zadnja godina ustanka navodi 70. jer je tada osvojen Jeruzalem i spaljen Hram, što je također prihvatljivo.

2 Transliteraciju hebrejskoga nazivlja radio sam izravno, a ne preko engleskoga jezika. Tako, primjerice, budući da u hrvatskom kao i u hebrejskom jeziku postoji slovo š (ש)), piše midraš i šalom, a ne midrash i shalom. Iznimku čine imena autora čija su djela, a time i imena, preuzeta iz engle- 
autori Barnabine poslanice ili Petrova otkrivenja, te arheološki nalazi iz Judejske pustinje, uključujući numizmatički materijal. Oskudnost izvora djelomice se može pripisati razmjerno niskoj razini percipirane važnosti ustanka u vrijeme kad se odvijao, kao i sustavnom razaranju judejskih uporišta nakon njegova sloma. Tek kroz kasnija tumačenja, nakon što su razmjeri nacionalne nesreće koju je ustanak izazvao za Židove postali prepoznati, shvaćanje važnosti toga ustanka bitno je poraslo. To se poglavito dogodilo unutar židovskoga nacionalnoga korpusa, te u manjoj mjeri među kršćanima. Iz poslijeustaničkoga shvaćanja ustanka potom su proizišla brojna vrela, ali pristrana i obojana sukladno tim tumačenjima. Nesklonost prema ustanku i njegovu vođi dade se skoro bez iznimke iščitati iz svih izvora, ne samo rimskih i kršćanskih, nego i židovskih. Premda iz toga razdoblja povijesti ne možemo očekivati nepristrana historiografska vrela, ni jednostranost kakvu nalazimo u izvorima o Bar Kohbinu ustanku nije sasvim uobičajena. Uobičajenije je imati pristrane izvore ali s različitih očišta i međusobno suprotstavljene. Arheološki nalazi iz druge polovice 20. stoljeća omogućili su neke nove spoznaje o prirodi i tijeku ustanka, ali možda prije svega drugoga — poglavito kroz otkrivanje stvarnoga imena ustaničkoga vođe — opseg te jednostrane nesklonosti.

\section{Razlozi za ustanak i izvori}

Vjerodostojni i provjerljivi izvori o Drugom židovskom ustanku toliko su oskudni da se ni o razlozima početka pobune, ni o njezinim zemljopisnim razmjerima, ni o tijeku rata, pouzdano ne zna skoro ništa (Gichon, 1986, 15). ${ }^{3}$ Jasno je tek da je cilj ustanka bio zbacivanje rimske vlasti i obnova židovske političke i vjerske suverenosti u Judeji, te obnova Hrama i hramskoga bogoštovlja u Jeruzalemu. Teško da je postojala bitnija židovska zajednica koja u vrijeme ustanka postizanje takva cilja nije smatrala poželjnim. Stoga bi bilo za očekivati da židovski izvori prenose blagonaklonu sliku o ustanku i o ustaničkim vođama. Ali nije tako. Židovski izvori, poglavito dio rabinske literature čije su knjige dovršene do početka 6. stoljeća (midrašim, Talmud), ustanak, a osobito njegova vođu, prikazuju u lošem ili, rjeđe, u ambivalentnom svjetlu. Slično vrijedi i za kršćanske izvore, a u rimskima se on ni ne spominje. Ustanak je u Judeji buknuo 132. godine, izgledno u ljeto, premda postoje određeni izvori koji njegov početak pomiču nešto ranije, do mjeseca nisana, odnosno proljeća iste godine (Katz, 2006, 111-112). Ustanici su zauzeli čitavu Judeju, a vjerojatno i neka područja Pereje s druge strane Jordana. ${ }^{4}$ Jedno od središta ustanika bio je Herodion i oaza Ein Gedi (עין גדי), kamo

skoga jezika. Primjerice ime יגאל ידין u članku se javlja u engleskoj transkripciji Yigael Yadin. Više o toj temi usp. Havel i Kasapović, 2016. Svi prijevodi s hebrejskoga i engleskoga jezika u članku su autorovi, ako nije drukčije naznačeno.

3 Također usp. Katz, 2006, 105.

4 Da je ustanak zahvatio Judeju (pri čemu valja imati na umu kako granice Judeje nisu bile jasno određene), a izgledno i veće dijelove okolnih zemalja, može se zaključiti iz podataka o uništenim utvrdama i naseljima koje daje Dion (1925, 449-451), rečenice iz Jeronimova Ljetopisa prema 
su se od nasilja Rimljana sklonili neki od židovskih izbjeglica nakon što su napustili domove u prekojordanskim krajevima. Galileja izgledno nije bila zahvaćena ustankom, premda se u nekim Bar Kohbinim pismima spominju Galilejci, pa dio povjesničara smatra da su mu se i oni priključili. No kontekst u kojem se spominju je nejasan, kao i sama riječ גללאים, koja se može protumačiti i na druge načine, a ne samo kao "Galilejci" (Mor, 2016, 171). ${ }^{5}$ Jeruzalem je najvjerojatnije tijekom čitavoga trajanja ustanka ostao pod vlašću Rimljana: usprkos brojnim aluzijama iz različitih tekstova ne postoji pouzdan dokaz niti da su ustanici oslobodili Jeruzalem, niti da su Rimljani od ustanika opet osvojili grad (Mor, 2016, 287). ${ }^{6}$

\subsection{Ime ustaničkoga vođe prema različitim izvorima}

Ime Bar Kohba (בר כוכבא), koje nosi mesijanski prizvuk, sačuvano je samo u izvorima iz pera kršćanskih autora, odnosno ranih crkvenih otaca (Yadin, 1971, 18) i Euzebija, u čijim se tekstovima naziva B $\alpha \rho \chi \omega \chi \varepsilon \beta \alpha \varsigma$. Ali to nije njegovo stvarno ime, premda su povjesničari dugo smatrali da jest. Bar Kohba je izvedenica iz stvarnoga imena i zapravo predstavlja titulu. Izvorno je ime pronađeno tek početkom 1950-ih u pismima iz Judejske pustinje što su napisana u vrijeme ustanka. Iz tih su pisama povjesničari prvi put saznali pravo i puno ime ustaničkoga vođe (Yadin, 1971, 29), koje glasi Šimon Ben Kosiba (שמעון בן כוסבא) ili Šimon bar Kosiba (שמעון בר כוסבה). Zadnje slovo imena אמון aramejski je, a je hebrejski oblik pisanja istoga imena. U nekim se pismima pojavljuje i oblik כושר (Yadin, 1961a, 50), u kojem je slovo sameh (ס) zamijenjeno slovom sin (ש), što je izgledno pogrješka koja se u tim pismima javlja i kod pisanja riječi שלום (šalom). Kao što je, vjerojatno tijekom ustanka, ime Bar Kosiba pretvoreno u mesijanski oblik Bar Kohba, tako je nakon ustanka isto ime u židovskim vrelima opet izmijenjeno, ali taj put ne s mesijanskim, nego s podrugljivim prizvukom. U njima se ustanički vođa naziva Bar Koziba (בר כוזיבא) ili Ben Koziba (בן כוזבה ,בן כוזיבא). ${ }^{7}$ To se ime pojavljuje u talmudskim knjigama i predstavlja igru riječi. Svaki je taj oblik sličan prvomu imenu kod izgovora i pisma, ali ne i kod značenja. Riječ כוכב (kohav) znači "zvijezda", a riječ כוזב (kozav/kazav) znači “prijevara”. Značenje imena כוכב (אבר

kojoj su Židovi tijekom šesnaeste Hadrijanove godine »uzeli oružje i opustošili Palestinu « (Jeronim, 2005) te Sulpicije Sever koji piše da su Židovi »pokušali opljačkati i Palestinu i Siriju « (Severus, 1890-1900, poglavlje 31, str. 242). Na temelju tih i drugih izvora neki povjesničari smatraju kako se ustanak proširio ne samo do Galileje i prekojordanskih krajeva, nego i do Sirije. Drugi pak smatraju da su ustanici zauzeli samo dijelove Judeje južno od Jeruzalema. Više o različitim tumačenjima opsega ustanka usp. Mor, 2016, 146-152.

5 Usto se riječ Galileja u biblijskom hebrejskom (Iz 8,24 u Hebrejskoj Bibliji 8,23) piše גליל.

6 Usp. Gibson, 2007, 162. Za suprotno mišljenje usp. Yadin, 1971, 18. I Abramsky smatra da su pobunjenici zauzeli Jeruzalem (Abramsky, 2007, 159). On se poziva na kovanice iz vremena ustanka s natpisom לחרות ירושלים ("za slobodu Jeruzalema”), što je općenito ključni argument povjesničara koji smatraju da su ustanici zauzeli Jeruzalem (Mor, 2016, 255). Schürer prenosi izvješće Apijana iz Aleksandrije (oko 95.-165.), koji je kao suvremenik pisao o tim događajima kao primjer izvora prema kojem su Rimljani u Hadrijanovo vrijeme nasilno osvojili Jeruzalem (Schürer, 1973, 550).

7 Podrobnije o imenima ustaničkog vođe usp. (Abramsky, 2007, 156-157). 
sačuvano u kasnijim kršćanskim spisima ${ }^{8}$ je "sin zvijezde", što je aluzija na proroštvo iz Svetoga pisma “od Jakova zvijezda izlazi, od Izraela žezlo se diže" (Br 24,17), na hebrejskom כוכב מיעקב וקם שבט מישראל " Značenje talmudskoga imena בר כוזיבא je "sin prijevare".

\section{Dionov opis ustanka}

Židovski su izvori, kao i kršćanski, usredotočeni na evaluaciju ustanka, a ne na kronologiju zbivanja. Zato je rimski povjesničar Dion Kasije (155.-235.) koji ustanak opisuje u Rimskoj povijesti, korisniji za uvid u tijek ustanka. Prema Dionu $^{10}$ rimski je car Hadrijan (117.-138.) u Judeju stigao godine $130 .{ }^{11}$ te je na mjestu porušenoga Jeruzalema dao utemeljiti novi grad po imenu Aelia Capitolina (Dion, 1925, 446-447). Hadrijan je općenito bio poznat po graditeljskim pothvatima, pa ne bi bilo neočekivano da je na prizor možda jedinoga devastiranoga grada u Carstvu dao da se to mjesto obnovi, ali i preimenuje po njemu. Ako su preimenovanje Jeruzalema i gradnja rimske kolonije s pripadajućim svetištem

8 Kršćanski autori Bar Kohbino ime nisu sačuvali u njegovu mesijanskom značenju kako bi mu dali na važnosti, nego je moguće da im ime Bar Kosiba nije ni bilo poznato. Usto, kršćanski autori nisu prihvaćali talmudski diskurs i tumačenja (mnogi su talmudski tekstovi postojali i prije nego što je čitava zbirka kanonizirana). U kršćanskim tekstovima ne nalazimo igru riječi kao u židovskima, pa ga kršćani ne nazivaju Bar Kozibom. To se s jedne strane može objasniti činjenicom da od 3. stoljeća hebrejski (a uvelike i aramejski) jezik u Crkvi, poglavito među intelektualnom elitom, čiji su pripadnici nerijetko prije obraćenja obrazovani u različitim filozofskim školama prožetima helenizmom, nije bio ni približno zastupljen kao grčki, pa većina kršćana ne bi ni razumjela ironiju i igru riječi. S druge strane, budući da je Bar Kohba poražen i ubijen, a njegov se je pokret raspao, bilo je jasno da nije bila riječ o Mesiji, pa je uporaba njegova mesijanskoga naslova sama po sebi već bila rugalica Židovima. Kršćanskim je autorima priča o neuspjelu mesijanskom liku bila prikladan dokaz usuda onih koji zanemare evanđelje i pristanu uz lažne proroke i pomazanike, što se pokazalo po plodovima u skladu s Isusovim upozorenjem iz Mt 7,15-20. Židovi su se, prema kršćanskom shvaćanju, odbacivši Isusa kao Mesiju uzdali u laž, a to je bio i oblik Božje kazne, jer je Bar Kohba na židovski narod navukao golemu nesreću u vidu progona i protjerivanja. Slično se može reći i za kršćansko čuvanje i prepisivanje drugih dragocjenih povijesnih spisa čiji su autori Židovi, poput djela Josipa Flavija. Židovi su Josipa dugo smatrali izdajnikom, jer je bio prebjeg, a njegove su knjige zapostavljene u židovskoj tradiciji i rabinskoj literaturi. Kršćanski razlog za čuvanje Flavijevih djela, osim što su pružala kontekst u kojem je nastalo kršćanstvo, bilo je i pokazivanje usuda koji je zadesio židovski narod i njihove svetinje zbog odbacivanja Krista. Tu je, dakako, i Flavijev opis Isusova poslanja Testimonium Flavianum (Antiquitates Judaicae, XVIII.3.3), no s obzirom na nejasno podrijetlo i kratkoću toga ulomka, taj aspekt ne bi trebalo prenaglašavati. Jedna od središnjih tema Flavijeva literarnoga opusa opis je rimske opsade Jeruzalema, koja je završila uništenjem Hrama, što kršćani smatraju ispunjenjem Isusova proroštva kako od te veličanstvene građevine kojom su se Židovi ponosili »neće ostati ni kamen na kamenu« (Lk 21,6).

9 Usp. JT Ta'anit 24a.

10 Dionov opis rata nalazi se u njegovu djelu Rimska povijest LXIX, 12-15, koje je, premda je Dion rimski povjesničar, pisano na grčkom jeziku. Ovdje korišteni izvor je Dio's Roman History with an English Translation iz 1925., u kojem se usporedno nalazi grčki izvornik i engleski prijevod. Za pregled Dionova izvješća s komentarima također usp. Gichon, 1986, 15-43.

11 Hadrijanov dolazak u Judeju 130. obilježen je u Rimu izradom brončanih kovanica (Meshorer, 1982, 132), pa se taj podatak smatra neupitnim. Više o Hadrijanovu boravku u Judeji, građevinskim radovima poduzetima u kontekstu njegova dolaska itd. usp. Smallwood, 2001, 431-437. 
prethodili ustanku, kako tvrdi Dion, vrlo je moguće kako Hadrijan tim činom nije želio izazivati Židove niti omalovažiti njihove svetinje, nego je postupao kao i drugdje u Carstvu: obnavljao je porušeno, a urbanistička i arhitektonska rješenja logično su odražavala duh rimske civilizacije. Štoviše, nije nezamislivo ni da je Hadrijan od lokalnoga židovskoga stanovništva očekivao zahvalnost zbog obnove Jeruzalema koju je pokrenuo, te da je ustanak doživio kao uvrjedu.

Na mjestu gdje je nekoć stajao židovski Hram, Hadrijan je podignuo novi, ali posvećen Jupiteru, vrhovnomu rimskomu božanstvu (Dion, 1925, 446-447). Što god da je bio Hadrijanov motiv, Židovi su to shvatili kao gnjusno, nedopustivo oskvrnuće njihova najsvetijega mjesta. Smještanje svetišta kulta poganskoga božanstva na mjestu Hrama Boga Izraelova mnoge je Židove jamačno podsjetio na slično svetogrđe koje je nekoć počinio Antioh IV. Epifan, koji je u Hramu podignuo Zeusovo svetište i ondje žrtvovao nečiste životinje (1 Mak 6,1-5). Sjećanje na Makabejski ustanak i susljedno razdoblje kraljevine Hasmonejaca nedvojbeno je imalo ulogu u nadahnuću i poticanju Židova na pobunu. Židovi su, prema Dionu, čekali pogodan trenutak za ustanak, koji nije dolazio dok je car boravio u Judeji i okolnim krajevima. Judeja je tijekom Hadrijanova obilaska Egipta i Sirije ostala mirna (Dion, 1925, 446-447). Dion prenosi i da su židovski kovači, kojima su Rimljani donosili oružje na popravak ili izradu, posao radili loše, kako bi Rimljani to oružje odbacili kao neprikladno, te kako bi ono palo Židovima u ruke. Takvo loše izrađeno oružje arheološkim iskapanjima nije pronađeno (Katz, 2006, 108), no Dionova opaska upućuje na to da je ustanak bio pomno planiran, da su se Židovi za njega pripremali i da nije bio spontan. Štoviše, pripreme za ustanak u tom su slučaju trajale godinama jer se takvo oružje nije moglo proizvesti drukčije nego pomalo. Pretpostavku o dugotrajnim pripremama za ustanak potvrđuje i Dionov navod prema kojem su Židovi na pogodnim mjestima diljem zemlje izgradili utvrde, te niz podzemnih skrovišta, skladišta i prolaza s otvorima za zrak i svjetlo (Dion, 1925, 446-449). ${ }^{12}$

Ustanak je planuo kad se je Hadrijan, koji je nakon Judeje proputovao Arabiju te se neko vrijeme zadržao u Egiptu, udaljio od Orijenta (Goold, 1921, 1991, 44-45). Da je za ustanak postojala određena osmišljena strategija što su ju ustanici primjenjivali na većini mjesta na kojima je izbila pobuna, također proizlazi iz Dionova opisa: ustanici se nisu s Rimljanima frontalno sukobljavali, jer je u takvim okršajima prednost bila na strani bolje opremljenih, uvježbanijih i iskusnijih rimskih vojnika. Glavna ustanička strategija bilo je gerilsko ratovanje: napadali su Rimljane neočekivano, a potom se povlačili u pripremljena utvrđena mjesta i podzemna skrovišta. Rimljani isprva nisu pridavali veliku pozornost tim napadima. Tumačili su ih kao ispade lokalnih nezadovoljnika. No kao i mnogo puta ranije u Judeji, pogriješili su u procjeni kako opsega tako i prirode ustanka. Dion navodi kako je nedugo zatim došlo do previranja među Židovima diljem Judeje,

12 Arheolozi su pronašli neke od tih podzemnih skrovišta, povezanih uskim prolazima kroz koje često može prolaziti samo jedna osoba, s tajnim ulazima koji primjerice sliče na grobnicu (Mantel, 1968b, 286-287). Više o izgledu i svrsi podzemne ustaničke infrastrukture usp. Gichon, 1986, $23-33$. 
a njihovo se neprijateljstvo prema Rimljanima očitovalo kroz prikrivene i otvorene nasrtaje. Kako su ustanici počeli nizati uspjehe u borbama, pridruživao im se i veći broj sunarodnjaka iz Judeje, a potom i iz drugih dijelova Rimskoga Carstva. $\mathrm{Na}$ to da je ustanički uspjeh bio velik ukazuje Dionova opaska kako su im se pridružili i mnogi nežidovi koji su se polakomili za ratnim plijenom. Ustaničke pobjede i plijen mora da su bili golemi i ukazivali na održivost takvih prilika, kad su drugi podanici Carstva procijenili da je isplativo savezništvo sa židovskom, a ne s rimskom stranom. Pobuna se je iz Judeje, prema Dionu, proširila i na druge pokrajine. Dionovim riječima »čitava se je zemlja, moglo bi se reći, uskomešala oko te [židovske] stvari« (Dion, 1925, 448-449). Tek je 133. godine Hadrijan shvatio da će za gušenje pobune u Judeji morati pokrenuti opsežan vojni pohod. Na čelo vojske postavio je »svoje ponajbolje generale«, a prvi koji je stigao u Judeju bio je vojskovođa Julije Sever, koji je do tada upravljao Britanijom.

Rimljani su do Severova dolaska u Judeju pretrpjeli velike gubitke. Jedan od većih poraza dogodio se je kad je iz Egipta prema Jeruzalemu krenula Dvadeset druga legija Deioteriana, koju je ustanička vojska potpuno uništila. Kad je Sever okupljao vojsku za gušenje ustanka, i Hadrijan je krenuo prema jugu kako bi bio bliže žarištu zbivanja. Sever se u rat protiv židovskih ustanika uključio 133. godine. Do tad su se vojne prilike u Judeji posve izmijenile: sada su Rimljani bili ti koji se nisu usuđivali ulaziti u frontalne sukobe s ustanicima. ${ }^{13}$ Razlog koji Dion navodi židovska je brojnost i očaj s kojim su se branili. Umjesto toga, rimske su čete, podijeljene u mnoštva manjih skupina, opkoljavale pobunjenike u njihovim utvrdama, odsijecale ih od veze s izvanjskim svijetom te ih iscrpljivale glađu i žeđu. Tako je, piše Dion, osvojeno i do temelja uništeno pedeset najvažnijih židovskih utvrda te čak 985 naselja. Navodi i da je u bitkama palo 580.000 ljudi, a broj je onih koji su izginuli od gladi, bolesti i vatre neizmjerljiv (Dion, 1925, 449-451). Usto je i broj rimskih žrtava bio neočekivano velik. Koliki su bili rimski gubitci u tom ratu protiv Židova, Dion oslikava u navodu kako te godine (vjerojatno 134.) Hadrijan pismo upućeno Senatu nije započeo uobičajenom preambulom, čiji je završni dio glasio mihi et legionibus bene, odnosno "ja i legije smo dobro" (Dion, 1925, 450-451). Nakon što je napokon ugušio ustanak, Hadrijan pobjedu nije proslavio podizanjem slavoluka pobjede ni izradom prigodnih kovanica, kako su Rimljani učinili nakon sloma Prvoga ustanka. Dapače, stječe se dojam kako mu je namjera bila rat u Judeji prikazati kao događaj nevrijedan osobite pozornosti (Wise, 2015, 1-2; Syme, 1988, 167).

Judeja je nakon rata gotovo posve svedena na opustošenu pokrajinu. Dion na kraju izvješća o ustanku piše kako je Židovima prije pobune stiglo upozorenje o sudbini koja će zadesiti njihov narod i zemlju, jer se je Salomonov grob, koji su Židovi štovali, sam od sebe raspao, a vukovi su i hijene nahrlili u njihove gradove. Ime vođe židovskoga ustanka Dion u tekstu ne navodi.

13 Određena se nedosljednost može iščitati iz toga Dionova opisa, jer je ranije naveo kako se Židovi nisu usuđivali frontalno sukobiti s Rimljanima. Više o tom usp. Gichon, 1986, 19-23, gdje autor nudi moguća pojašnjenja i rekonstrukciju bitki. 


\section{Bar Kohbin ustanak prema drugim izvorima}

Među razlozima za izbijanje ustanka koje nalazimo u drugim izvorima ${ }^{14} \mathrm{su}$ nezadovoljstvo judejskih Židova ratovima koje je Rim ranije vodio protiv Židova od Cirenaike (Libije) do Mezopotamije (Yadin, 1971, 18) te Hadrijanova primjena zabrane sakaćenja spolovila kod muškaraca, što ju je uveo Trajan, tako da se odnosi i na obrezivanje. Obrezivanje nije bilo zabranjeno kao vjerski običaj, nego kao barbarski čin, a za njega se nije koristio poseban naziv, nego je obrezanje bilo obuhvaćeno izrazom mutilare genitalia (Smallwood, 1959, 340). Primjena te zabrane bila je na snazi samo tijekom Hadrijanove vladavine, jer ju je već njegov nasljednik Antonin Pio (138.-161.) ukinuo u smislu da se više ne odnosi na Židove. Razlog Hadrijanove zabrane, kao i Antoninova poništenja, nisu jasni. Hadrijan je odredio da se kršenje zabrane obrezivanja kažnjava prema istom zakonu kao i ubojstvo, no ne zna se kad je to učinio i zbog čega. Štoviše izvori su proturječni po pitanju toga je li zabrana obrezivanja bila razlog ili posljedica pobune (Smallwood, 1959, 334-335). Izglednije je da je bila posljedica jer je teško pretpostaviti da bi Hadrijan promijenio postojeći zakon i uvodio zabranu obrezivanja narodu koji je taj čin shvaćao kao temeljni znak pripadnosti zajednici i vjeri, i od kojega se u slučaju takve zabrane ništa manje od pobune nije moglo ni očekivati (Smallwood, 2001, 431).

\subsection{Barnabina poslanica, Elije Spartijan, biskup Epifanije}

U Barnabinoj se poslanici, napisanoj prije ustanka, vjerojatno oko $130 .{ }^{15}$ nalazi rečenica koja ukazuje na to da je Židovima već u to vrijeme bilo zabranjeno obrezivanje, što bi značilo da je zabrana prethodila ustanku. Takvo tumačenje kao moguće predlaže Smallwood $(1959,336),{ }^{16}$ premda je dojam da je taj dio Barnabine poslanice lakše iščitati kao teološku polemiku heleniziranoga kršćanina sa Židovima nego kao referencu na Hadrijanovu zabranu obrezivanja. ${ }^{17}$ Izravnu tvrdnju da je Hadrijan Židovima zabranio obrezivanje prije ustanka nalazimo u Hadrijanovoj biografiji, koju je koncem 3. stoljeća napisao Elije Spartijan, ${ }^{18}$ što je povezivo s Dionovom tvrdnjom kako je rat izbio zato što je Hadrijan utemeljio Aeliju Capitolinu i podignuo Jupiterov hram (Dion, 1925, 446-447). Biskup Epifanije Salaminski koncem 4. stoljeća piše da je Hadrijan u Jeruzalem stigao 47

14 Popis izvora u kojima se spominje Bar Kohba nalazi se u: Yadin, 1971, 255-259.

15 Usp. Uvod u pseudo-Barnabinu poslanicu (Apostolski oci II., 2010, 101).

16 Autorica nakon uvida u židovske izvore potpuno prihvaća da je zabrana obrezivanja prethodila ustanku (Smallwood, 1961, 93-96).

17 Riječ je o ulomku iz Barnabine poslanice 9,4 koji glasi: »A obrezanje u koje su se oni [Židovi] uzdali obeskrijepljeno je. Tä Gospodin je govorio o obrezanju koje ne treba činiti na tijelu, međutim, oni su prekršili zapovijed jer ih je zaveo zli anđeo« (Apostolski oci II., 2010, 124). Također usp. Paget, 1991, gdje autor ulomak tumači kao vjersku polemiku, a ne kao dokaz postojanja Hadrijanove zabrane obrezivanja.

18 Usp. Aelii Spartiani De Vita Hadriani XIV.2 (Goold, 1921, 1991, 45). Također usp. Mantel, 1968a, 225 . 
godina nakon što je Tit uništio Hram. Zatekao je grad u ruševinama »s iznimkom nekoliko kuća i omanje crkve Božje, u koju su se učenici, nakon što je Spasitelj uzišao s Maslinske gore, vratili i otišli u gornju sobu «. Hadrijan je odlučio izgraditi grad, ali ne i Hram. Za nadglednika radova postavio je Akvilu, te je, »budući da se je zvao Aelius Hadrijan, grad nazvao Aelia « (Epiphanius, 1935, 30). ${ }^{19}$ Godina početka Hadrijanove obnove Jeruzalema je, prema Epifanijevu izvješću, 117. ${ }^{20}$

\subsection{Euzebije Cezarejski, Talmud i rabin Akiva}

O Bar Kohbi piše Euzebije u kratkom ulomku u kojem su on i židovska pobuna, očekivano, opisani bez ikakve naklonosti: »Tada je židovski vojskovođa bio čovjek po imenu Bar Kokeba. To znači zvijezda. Bio je inače čovjek ubojica i razbojnik. Međutim, svojim se imenom nametnuo kao robovima. Lagao je da je tobože kao svjetlo sišao s neba da ih u nevoljama prosvijetli« (Euzebije, 2004, 376).

Jedan od razloga Euzebijeva gruboga opisa ustaničkoga vođe podatak je, koji je preuzeo od Justina Mučenika, kako je Bar Kohba progonio kršćane: »Isti Justin, spominjući tadašnji rat protiv Židova, ovo dodaje: 'Za sadašnjega je židovskog rata Bar Kokeba, vođa židovske pobune, naredio da se privedu strašnim mukama samo kršćani ako se ne odreknu Isusa Krista i ako na nj ne pohule' « (Euzebije, 2004, 382).

Za razliku od Spartijana i biskupa Epifanija, Euzebije u Crkvenoj povijesti opisuje Hadrijanove protužidovske odredbe kao posljedicu ustanka, a ne kao razlog. Među Hadrijanovim kaznenim odredbama Euzebije navodi progon židovskoga naroda iz Jeruzalema, preimenovanje Jeruzalema u Aelia Capitolina i izgradnju Jupiterova hrama na mjestu spaljenoga Drugoga hrama (Euzebije, 2004, 376-377). Mantel smatra kako su Euzebijevi navodi vjerodostojniji od Spartijanovih, pa u zaključnim opažanjima ponovno tvrdi da Bar Kohbin ustanak nije bio potaknut vjerskim progonom što mu je prethodio, nego da je bila riječ o spontanom ustanku Židova protiv rimske vlasti (Mantel, 1969, 341-342). Talmud također donosi slijed prema kojem je Aelia Capitolina utemeljena nakon, a ne prije ustanka: »Devetoga [dana] ava [mjeseca] presuđeno je ocima našim da ne će ući u zemlju [Izraelovu], i Hram je bio uništen prvi put pa drugi put, Beitar je zauzet, a grad [Jeruzalem] uzoran. «21

Nakon Hadrijana Židovima je ponovno dopušteno obrezivanje, što je potvrđeno i u Justinijanovu Zborniku civilnoga prava iz 533., prema kojem je »samo Židovima dopušteno obrezivanje njihovih sinova; osoba koja to napravi a ne pripada njihovoj religiji kaznit će se kao da je počinila kastraciju« (Watson, 1998,

19 Epifanije dalje u tekstu ne govori o obnovi grada, nego o tom kako se nadglednik Akvila obratio na kršćanstvo, ali je potom otpao od vjere jer je bio privržen tumačenju horoskopskih znakova. Nakon što ga je Crkva izopćila obratio se na židovstvo, naučio hebrejski te napravio novi prijevod hebrejskoga Svetoga pisma na grčki. Taj je prijevod, Epifanije dalje piše, za razliku od Septuaginte bio loš i netočan, jer je Akvila izmijenio neke riječi kako se iz njih ne bi razaznala proroštva o Kristu.

20 Hram je uništen 70. pa je 47 godina kasnije 117. godina.

21 BT Ta‘anit 26b (בתשעה באב נגזר על אבותינו שלא יכנסו לארץ וחרב הבית בראשונה ובשניה ונלכדה ביתר ונחרשה). 
335). U kodeksu se navodi "obrezanje" (circumcidere), a izvor zakona je tekst Modestina, jednoga od pet pravnika na čijim se djelima temelji Zakonik civilnoga prava i koji je pisao sredinom 3. stoljeća. Modestin je bio učenik Ulpijana, pravnika čija su djela najzastupljenija u Zakoniku. Modestin se u uvodu poziva na Pija (Antonina) kao autora ove uredbe. Židovska tradicija kao razlog ustanka spominje i Hadrijanovo obećanje da će Židovima obnoviti jeruzalemski Hram. Prema midraškom tekstu Berešit raba, Židovi su se pobunili nakon što se Hadrijan predomislio jer su se na tu odluku žalili Samarijanci (Yadin, 1971, 21-22). ${ }^{22}$

Ime ustaničkoga vođe Bar Kohba "sin zvijezde", kako su ga nazivali sljedbenici i suborci, potječe od tumačenja stihova Knjige brojeva 24,17 koje je dao rabin Akiva. Proroštvo "od Jakova zvijezda izlazi, od Izraela žezlo se diže," on je primijenio na Bar Kohbu, čime ga je prepoznao kao Mesiju. Tomu u prilog govore i dokumenti iz toga razdoblja pronađeni u Judejskoj pustinji u kojima se ustanički vođa oslovljava mesijanskim naslovom נשיא ישראל (nasi israel) odnosno "knez Izraela" ili u Yadinovu prijevodu "predsjednik Izraela" (Yadin, 1971, 175), što je moderno značenje te riječi. Riječ "Mesija" (משיח) u tim se pismima ne spominje. Bar Kohba (odnosno Koziba) se Mesijom, ali samozvanim, naziva u Talmudu: »Bar Koziba je vladao dvije i pol godine. Mudracima je rekao: 'Ja sam Mesija [משיח].' «23 Rabi Akiva ga je, jedno kratko vrijeme, smatrao Mesijom (Da-Don, 2004, 702). Vidjevši ga izjavio je: »On je kralj Mesija [מלכא משיחא]. Na to mu je sugovornik, rabi Johanan Ben Torta uzvratio: »Akiva, trava ce rasti iz tvojih obraza, a sin Davidov doći još neće. ${ }^{24}$

\subsection{Sveti Jeronim i Justin}

Sveti Jeronim (oko 347.-420.) u Apologiji protiv Rufina spominje Bar Kohbu kao vođu židovskoga ustanka koji je svoje sljedbenike zavodio da vjeruju kako je u stanju rigati vatru (Jeronim, 1906, 535). ${ }^{25}$ Jeronim tim opisom sugerira ono što se o Bar Kohbi iščitava i iz Bar Kohbinih pisama i židovskih izvora, da je bio odlučan i karizmatičan čovjek, prkosne snage, žilavosti, odlučnosti i odrješitosti koja ne trpi protivljenje (usp. Yadin, 1971, 124). Naredbe što ih je upućivao podređenim zapovjednicima nisu ostavljale prostora za raspravu, nego su nerijetko bile popraćene prijetnjom da će, ne postupi li po zahtjevu, primatelj pisma biti kažnjen. Snaga takve osobnosti, skupa s potporom uglednoga i utjecajnog rabina

22 Poglavlje o Bar Kohbinu ustanku Schürer otvara navodeći tu »židovsku legendu«, ali ju ne smatra povijesno utemeljenom (Schürer, 1973, 535). Berešit raba (בראשית רבה) je midraški tekst dovršen u 4. ili 5. stoljeću. U 64. poglavlju spominju su se כותתָאים (ברזים; što je aramejski naziv za Samarijance; za to objašnjenje zahvalan sam rabinu Kotelu Da-Donu) koji odvraćaju kralja od gradnje Hrama, nakon čega Židovi snuju pobunu, ali se ta priča ne može jasno povezati s Bar Kohbinim ustankom.

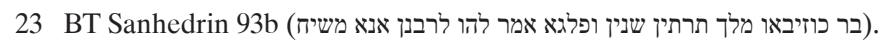

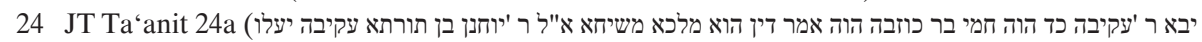
(עשבים בלחייך ועדיין בן דוד לא (עלו).

25 Također usp. Mor, 2016, 399. 
Akive, a možda i velikoga svećenika, ${ }^{26}$ od njega su stvorili lidera kojega su Židovi vjerno slijedili. Za razliku od Prvoga ustanka, kad su se diljem Judeje pojavljivale veće ili manje skupine okupljene oko kakva mjesnoga lidera što se kadgod izdavao za Mesiju, taj put su pobunjenici prepoznali jednoga istoga vođu, te su za Bar Kohbom krenuli mnogi koji su priželjkivali propast rimske i uspostavu židovske uprave. Ne postoje izvori koji bi ukazivali na djelovanje drugih vođa. Iz postojećih se dokumenata razabire da je Bar Kohbina vlast obuhvaćala neko šire područje, ali i da nisu svi judejski Židovi ustali na pobunu. U jednom pismu Bar Kohba izdvaja stanovnike Tekoe kao one koji izbjegavaju vojnu službu, te od lokalnih zapovjednika traži da ih kazni. Tekoa je, zanimljivo je, i u Nehemijino vrijeme bio grad čije je plemstvo nastojalo izbjeći ratne nevolje (Neh 3,5). S obzirom na Bar Kohbinu potrebu da izda specifičnu zapovijed po pitanju neulaska jednoga grada u ustaničke redove, za pretpostaviti je kako je to bilo nešto neobično i kako je odziv drugih judejskih gradova na ustanak bio masovan. Masovna židovska potpora ustanku ukazuje na snažnu prisutnost praktičnoga mesijanizma, odnosno vjere kako će Židovi boreći se za svoju vjeru i zemlju postići ispunjenje biblijskih obećanja (Frankel, 1991, 6). U tom smislu postoji kontinuitet s ustankom od 66. do 73. godine, jer je i taj velikim dijelom bio potaknut mesijanskim očekivanjima. Drugi je ustanak bio razrađen u nekom obliku "glavnoga stožera" i nikakvi suparnici koji bi Bar Kohbino vodstvo stavljali pod upit, kao ni disidentske skupine, koliko je poznato, nisu se pojavili. Židovski je narod taj put bio politički, vjerski i vojno ujedinjen oko jednoga neupitnoga autoriteta. U tom je kontekstu Jeronimova opaska razumljiva i uklapa se u sliku o Bar Kohbi iz drugih vrela.

Logičnu iznimku u mesijanskoj percepciji Bar Kohbe činili su kršćani, koji su početkom 2. stoljeća još uvijek bili poglavito židovska sljedba. Židovski kršćani smatrali su mesijanska obećanja ispunjenima u Isusu i za Bar Kohbom nisu krenuli potaknuti mesijanskim, a time vjerojatno ni eshatološkim nadanjima. Židovski kršćani nisu prestali gajiti političku težnju za izraelskom neovisnosti i svrgavanju rimske vlasti samo zato što su bili Isusovi učenici (usp. Dj 1,6). Nije nezamislivo da se dio njih priključio ustanku radi političkoga cilja, neovisno o mesijanskoj percepciji ustaničkoga vođe koju nisu dijelili. O mogućem kršćanskom sudjelovanju u ustanku ne postoje nikakvi izvori, a o kršćanskim prilikama općenito neposredno prije, tijekom i nakon ustanka znamo vrlo malo. Justin Mučenik, autor koji je pisao nedugo nakon ustanka i živio nedaleko od njegova poprišta, ${ }^{27}$ zabilježio je kako Bar Kohba progoni kršćane, ali je vođu židovske pobune, dojam je, spomenuo usput, u kontekstu općenite tvrdnje o židovskom progonu Isusovih sljedbenika, u ulomku koji sadržava neočekivan anakronizam.

26 Svećenik Eleazar, čije se ime spominje na nekim ustaničkim kovanicama, možda je bio veliki svećenik. Njegov identitet nije poznat, ali je njegov ugled jamačno bio golem, jer se u protivnom ne bi spominjao na kovanicama.

27 Justin je živio u Samariji u vrijeme ustanka, a umro je 160. godine. Bio je kršćanin nežidovskog podrijetla koji je u nauk Crkve unio važne protužidovske teološke argumente pa se ne može smatrati nepristranim izvorom, ali to ne umanjuje važnost njegova kratkog opažanja. 
Justin piše kako je »egipatski kralj Ptolemej osnovao knjižnicu« te je od judejskoga kralja Heroda zatražio da mu pošalje židovske »proročke knjige«. Kad su mu došle na hebrejskom jeziku, dao ih je prevesti na grčki, jer Egipćani nisu razumjeli hebrejski.

»Kad je to učinjeno, knjige se kod Egipćana čuvaju sve do danas, a posvuda su dostupne i kod svih Židova koji, premda ih znaju čitati, njihovo značenje ne shvaćaju ispravno, nego nas smatraju protivnicima i neprijateljima pa nas kao i vi, kada mogu, progone i ubijaju, u što se i sami možete uvjeriti. Doista, i Bar-Kohba, vođa židovske pobune, u nedavnom je židovskom ratu naredio da se samo kršćane odvlači na strašne muke ako se ne odreknu Isusa Krista i ne prokunu ga« (Justin, 2012, 54-55).

Justin se tu referira na prijevod Septuaginte, koja je nastala dva stoljeća prije Herodova rođenja. To, naravno, ne predstavlja dokaz da je Justinov spomen Bar Kohbe historiografski neutemeljen, pogotovo zato što su to zbivanja kojih je on bio suvremenik, ali je ipak neočekivan. ${ }^{28}$ Bar Kohbin progon kršćana možda je imao manju teološku dimenziju od one koju su joj kasniji kršćanski autori pripisali, jer je vođa pobune kažnjavao i Židove koji mu se nisu priključili, neovisno o njihovim eventualnim pripadnostima sljedbama. To se razabire iz njegovih prijetnja stanovnicima Tekoe, koji nisu bili kršćani. Što god da se je zbivalo, nesudjelovanje, barem ne masovno, židovskih kršćana u ustanku skupa sa sunarodnjacima, kao i mogući progon kojemu su bili izloženi zbog vjere u Isusa, produbili su jaz između te dvije zajednice (Skarsaune, 2002, 202).

\subsection{Petrovo otkrivenje}

Kršćanski spis Petrovo otkrivenje ili Petrova apokalipsa iz prve polovice 2. stoljeća ${ }^{29}$ smatra se jednim od najvažnijih vrela o Bar Kohbi. Bauckham u opsežnom članku nudi tumačenje toga spisa kao djela nastala iz pera židovskoga kršćanina u vrijeme ustanka. Tema Petrova otkrivenja eshatološka su zbivanja, a jedan je dio posvećen izraelskomu lažnomu Mesiji koji će zavesti mnoštva (Bauckham, 1994, 601). ${ }^{30}$ Prihvati li se pretpostavka da je Petrovo otkrivenje napisa-

28 Skarsaune smatra kako se ne može isključiti mogućnost da je riječ o pogrješci do koje je došlo kod kasnijih prepisivanja Justinova teksta. Usto, uvažava i postojanje samarijanske predaje prema kojoj je ime Ptolemejeva časnika u Judeji bilo Herod, a koja je Justinu poslužila kao izvor, što su kao rješenje te zagonetke ranije predložili drugi autori (Skarsaune, 1987, 46, bilj. 62). Također usp. Justin, 2012, 54, bilj. 60, u kojoj prevoditelj navodi da je Justin na tom mjestu »očito pogriješio«.

29 Tekst Petrova otkrivenja s osnovnim podatcima o pronalasku, datiranju, jeziku i značaju dokumenta nalazi se u: Elliot, 2005, 593-615. Tu nije riječ o istoimenom tekstu koji je pronađen u knjižnici gnostičkih ranokršćanskih spisa Nadž Hamadi u Egiptu.

30 Autor Petrova otkrivenja tu se referira na Mt 24,23-24, gdje Isus upozorava svoje učenike na dolazak lažnih Mesija: »Ako vam tada tko rekne: 'Gle, evo Krista!' ili: ‘Eno ga!’ — ne povjerujte! Ustat će, doista, lažni kristi i lažni proroci i iznijeti znamenja velika i čudesa da, bude li moguće, zavedu i izabrane. « Također usp. Bauckham, 2007, 80-81. Skarsaune (2007, 385-389) objašnjava zašto smatra da je Bauckhamovo tumačenje prihvatljivo. Samuel Abramsky, autor prvoga dijela članka o Bar Kohbi u EJ, također smatra da se dio teksta Petrova otkrivenja odnosi na Bar Kohbu, te da su u njemu opisana mesijanska očekivanja Židova. No sliku koju to štivo nudi o samom 
no u vrijeme ustanka i da se taj dio odnosi na Bar Kohbu, što je vrlo izgledno, ono predstavlja još jedan dokaz da su mnogi Židovi Bar Kohbu smatrali Mesijom, pa u njemu nalazimo potvrdu spomenutih talmudskih navoda, kao i Euzebijevu tvrdnju da je progonio kršćane.

\section{Kovanice}

Kovanice iz vremena Drugoga ustanka predstavljaju najranije pronađeni materijalni dokaz o ustanku. Ustanici nisu kovali vlastiti novac, nego su davali da se prekuje rimski, što je imalo simboličku važnost (Katz, 2006, 113). Snažnu simboliku sadržavali su i oblici na kovanicama. Na dijelu kovanica proizvedenih prve godine ustanka pisalo je ישראל שנת אחת לגאלת ("prva godina izbavljenja Izraelova") i שמעון נשיא ישראל ("Šimun knez Izraela"), što je impliciralo Bar Kohbino mesijansko poslanje izbavitelja izraelskoga naroda (Meshorer, 1982, 136) ${ }^{31}$ Kovanice su bile ukrašene simbolima poput pročelja Hrama, komada hramskoga posuđa, palme, trube i harfe. ${ }^{32}$ Budući da Bar Kohbine kovanice nisu pronađene u Galileji, pretpostavlja se da ta pokrajina nije bila uključena u područja koja su držali ustanici, što ne znači da ustaničke čete nisu prelazile granice Judeje u sporadičnim napadima na tamošnje rimske postrojbe. Kako je na nekim kovanicama bio natpis "Za slobodu Jeruzalema" (ירושלים לחרות), dio povjesničara smatra da su ustanici zauzeli Jeruzalem. Drugi pak misle da su te kovanice imale promidžbenu i motivacijsku ulogu. U prilog te teze ide podatak kako je, od preko petnaest tisuća kovanica pronađenih u Jeruzalemu, tek nekoliko njih bilo prekovano, pa je moguće da su se one u gradu našle kao suveniri što su ih donijeli rimski vojnici, a ne kao sredstvo plaćanja. ${ }^{33}$

Kovanice su se proizvodile tijekom sve četiri (odnosno tri i pol) godine trajanja ustanka. Kasniji židovski izvori rijetko ih spominju, što treba tumačiti u širem povijesnom kontekstu. Flavije, primjerice, u ljetopisima o Prvom ustanku nije pisao o židovskim kovanicama, za Rimljane iritantnom simbolu judejskoga prkosnoga suverenizma, a spomen o njima i u talmudskom je tekstu vrlo oskudan. U Jeruzalemskom se Talmudu spominju kovanice iz vremena Bar Kohbina ustanka te one "jeruzalemske", za koje se pretpostavlja da se odnose na Prvi ustanak.

Bar Kohbi on smatra »tendencioznim prikazom « iz kojega se iščitava »mržnja koja je izobličila perspektivu kršćanskoga autora pa je lišena stvarne historiografske vrijednosti« (Abramsky, 2007, 159).

31 Mesijansko značenje riječi נשיא može se iščitati iz Ezekielove rečenice: »Postavit ću im jednoga pastira koji će ih pasti, slugu svoga Davida: on će ih sam pasti i bit će im pastir, a ja, Jahve, bit ću njihov Bog, i moj sluga David bit će im knez [ועבדי דוד נשיא בתוכם]. Ja, Jahve, rekoh!« (Ez 14,23-24).

32 Popis deset simbola koji su nađeni na kovanicama iz prve godine ustanka te njihov opis i značenje usp. Meshorer, 1982, 138-150.

33 Meshorer piše kako je u Jeruzalemu pronađeno 40.000 kovanica, a samo je jedna bila ustanička, $\mathrm{i}$ to iskovana zadnje godine ustanka 135., pa pretpostavlja da ju je u grad donio neki rimski vojnik (Meshorer, 1982, 134). 
Židovi su, kao i Rimljani, nakon sloma ustanka zabranili njihovu uporabu (Meshorer, 1982, 105-106).

Avi-Yonah pak smatra da su ustanici uspjeli zauzeti Jeruzalem. On piše da je Jeruzalem najprije napustilo rimsko civilno stanovništvo, a za njima su iz grada otišli i vojnici, koji ga u sljedeće tri godine nisu uspjeli vratiti pod svoju vlast (Avi-Yonah et al., 2006, 30). I on svoju pretpostavku temelji na kovanicama, od kojih su neke uz natpise o slobodi Jeruzalema i svećeniku Eleazaru (אלעזר הכהן) prikazivale pročelje Hrama. No kovanice s izvornim Eleazarovim imenom izrađene su samo tijekom prve godine ustanka, a sve su kasnije kovanice "hibridne", odnosno njegovo je ime naknadno dodano, pri čemu su one iz druge godine ustanka »iznimno rijetke« (Meshorer, 1982, 136-138). ${ }^{34}$ Eleazarov je identitet nejasan i ne može se isključiti mogućnost kako je riječ o velikom svećeniku iz vremena ustanka, kao ni to da su na Brdu Hrama uistinu obnovljeni žrtveni obredi. No to je malo vjerojatno jer je teško zamisliti da židovski izvori takvo što ne bi zabilježili. Eleazarovo ime može se povezati i sa svećenikom iz Modi‘ina, koji je bio jedan od duhovnih vođa ustanka, a kojega je Bar Kohba ubio zbog sumnje da je bio u dosluhu s Rimljanima. ${ }^{35} \mathrm{~S}$ druge strane Meshorer, znanstvenik koji je objavio neka od najvažnijih djela o židovskim kovanicama antičkoga doba, na temelju mjesta pronalaska ustaničkih kovanica, smatra kako ustanici nikad nisu zauzeli Jeruzalem, te da su kovanice izrađene drugdje, ne u Jeruzalemu (Meshorer, 1982, 134). U zborniku radova o arheološkim iskapanjima u Jeruzalemu 1968.-1974. (Yadin, 1976), osim što Avi-Yonah na jednom mjestu letimice, u zagradi, navodi kako je Jeruzalem u vrijeme ustanka bio pod židovskom vlašću, nikakvi arheološki pronalasci koji bi takvo što potvrđivali nisu navedeni, a u više od trideset radova koji obuhvaćaju sva bitnija povijesna razdoblja od biblijskoga do uspostave Države Izrael, ni u jednom se ne obrađuje Drugi ustanak.

\section{Bar Kohbina pisma i drugi arheološki nalazi iz Judejske pustinje}

Osobito važno arheološko otkriće čine pisma što ih je Bar Kohba upućivao podređenim ustaničkim zapovjednicima. Pisma su pronađena u Judejskoj pustinji početkom 1950-ih i 1960-ih, nedaleko od mjesta gdje su petnaestak godina ranije pronađeni Svitci s Mrtvoga mora. Prvi su se arheološki artefakti iz vremena Bar Kohbina ustanka pojavili koncem 1951., četiri godine nakon otkrića Kumranskih svitaka. Fragmente tekstova pisanih hebrejskim, aramejskim i grčkim jezikom pronašli su Beduini u špiljama gorja Judejske pustinje nedaleko od Mrtvoga mora, najprije u suhodolu Vadi Muraba'ata, odnosno hebrejski Nahal Durga. ${ }^{36}$ Među prvim je pronađenim artefaktima bio papirus s tekstom koji je

34 Autor navodi i kako povjesničari i numizmatičari nisu uspjeli objasniti to neobično pojavljivanje Eleazarova imena na kovanicama.

35 Taj je događaj opisan u rabinskom tekstu Midraš Tužaljki (מדרש איכה) 2,2-4, koji je nastao oko 5. stoljeća.

36 Mjesto prvih pronalazaka određeno je vrijeme bilo nejasno, jer su trgovci antikvitetima navodili krajeve pod jordanskom upravom, ili prekojordanske krajeve kao nalazišta, a u stvarnosti pred- 
počinjao pozdravom: »Od Šimuna ben Kosibe za Ješuu ben Galgoula i stanovnike utvrde, mir « (Yadin, 1971, 28-29). Tada su prvi put otkriveni puno ime i prezime vođe židovskoga ustanka, kao i izvorni oblik prezimena: Kosiba a ne Kohba ili Koziba. Devet godina kasnije pokrenute su opsežne istraživačke ekspedicije u špiljama južno od Ein Gedija. Izraelski su arheolozi uz logističku i planinarsku pomoć vojske tada pronašli nove artefakte iz vremena Bar Kohbina ustanka, a među njima su osim pisama bile i kovanice, posuđe, predmeti za kozmetičku i kućnu uporabu, te ostatci odjeće i oružja ustanika.

Za pronalazak većine pisama zaslužan je povjesničar i arheolog Yigael Yadin, ${ }^{37}$ koji je kasnije opisao pripreme i tijek arheološke ekspedicije. Pothvat je zbog nepristupačna terena, brojnih opasnosti i neočekivanih otkrića na trenutke više sličio na avanturističku nego na arheološku ekspediciju. Neposredno nakon nje Yadin nije objavio podrobniji sadržaj pronađenih pisama, nego tek sažetke, ${ }^{38}$ a opsežnije su se studije pojavile kasnije (Mor, 2016, 3-4). ${ }^{39}$

Yadin donosi uzbudljiv opis iskapanja u dugačkoj špilji s dva ulaza što se na kraju razdvaja u dva kraka i koja je nazvana Špilja pisama (מערת האיגרות). Špilja se nalazila u dolini Nahal Hever, na litici visokoj oko 200 metara, na čijem su vrhu 1953. pronađeni ostatci improviziranoga rimskoga opsadnog logora. Ustanici su se uskom i opasnom, ali lako branjivom stazom s vrha litice spustili do špilje. Budući da im nisu mogli prići, Rimljani su zaposjeli prostor iznad njih te im onemogućili bijeg. Tu su špilju dubine 150 metara s nekoliko komora povezanih uskim prolazima već bili oplijenili Beduini, a potom su 1953. ondje iskapanja proveli izraelski arheolozi. Yadinov je tim u nju stigao u ožujku 1960. ne očekujući puno novih otkrića. No uz pomoć vojske dovukli su opremu za iskapanje i rasvjetu, što im je omogućilo podrobniji pregled unutrašnjosti špilje.

meti su otkriveni unutar područja pod izraelskom upravom nakon uspostave Države Izrael 1948. godine. Razlog je kršenje izraelskih propisa o arheološkim otkrićima. Ti su propisi po nastanku države 1948. preuzeti od britanske mandatne uprave, a privatna komercijalna arheološka iskapanja njima su bila ograničena ili zabranjena. Iste je godine osnovan Izraelski odjel za antikvitete pri Ministarstvu obrazovanja, unutar kojega je sljedeće godine napravljen nacrt zakona o antikvitetima. Taj je zakon, hok ha-atikot (חוק העתיקות), usvojen tek 1978. i do danas je na snazi (usp. Kersel i Kletter, 2006, 320).

37 O tom na zanimljiv način govori Israel Eldad. On ukazuje na to kako je otkriće Bar Kohbinih pisama predstavljalo »izvanredan arheološki pronalazak «, te objašnjava: »Ali to nije najčudesniji dio priče. Pravo se čudo nalazi u činjenici da je osoba koja je pronašla pisma posljednjega židovskoga zapovjednika bio poznati arheolog general Yigael Yadin, praktično prvi zapovjednik nove židovske [izraelske] vojske« (Eldad, 2007, 69-70). Inače, Yadin je od 1963. do 1965. predvodio arheološka iskapanja na Masadi, utvrdi na litici također u Judejskoj pustinji nešto južnije od špilja s predmetima iz vremena Bar Kohbina ustanka, te je zaslužan za čitav niz važnih otkrića na temelju kojih je rekonstruirana jedna od najpoznatijih bitki iz vremena Prvoga ustanka (Yadin, 1966, 12-13). Yadin (1917.-1984.) je bio drugi zapovjednik Glavnoga stožera Izraelske vojske, od studenoga 1949. do prosinca 1952. Otac mu je bio Eleazar Sukenik (1889.-1953.), glasoviti arheolog s Hebrejskoga sveučilišta i prvi znanstvenik koji je prepoznao autentičnost Svitaka s Mrtvoga mora.

38 Yadin je dijelove otkrivenih pisama objavio 1961. u časopisu Israel Exploration Journal (Yadin, 1961a).

39 Mor ovdje pogrješno navodi 1989. kao godinu Yadinove smrti. Za Yadinov tekst o otkriću, sadržaju i jeziku (hebrejski i aramejski) Bar Kohbinih pisama usp. Yadin, $1961 b$. 
Arheolozi i njihovi suradnici najprije su pronašli teško dostupan odvojak, koji nitko od prijašnjih tragača za arheološkim dragocjenostima nije uočio. U njemu su se nalazile ljudske kosti, vjerojatno posmrtni ostatci ustanika i njihovih obitelji, koji su našli utočište u špilji, ali ju zbog rimske opsade nisu mogli napustiti te su pomrli od gladi i žeđi. Netko ih je kasnije sahranio umotavši ih u komade pletene odjeće, a neke su lubanje bile posložene u košaru (Yadin, 1961a, 38). Yadin napominje kako ni jedan primjerak pronađene tkanine nije bio izrađen od miješanih vunenih i lanenih vlakana, sukladno propisu Mojsijeva zakona iz Pnz 22,11 (Yadin, 1971, 69). Nakon što je na ulazu slučajno pronađena kovanica na kojoj s jedne strane piše "Šimun" a s druge "Sloboda Jeruzalema", general Avraham Jofe (אברהם יפה) koji se je u tom trenutku slučajno nalazio s arheološkim timom predložio je da se špilja pretraži minodetektorima. Tako je otkriveno brončano posuđe, uredno posloženo u košare i zakopano. Iz tih su predmeta prikupljeni podatci o ustanicima, a oni su potvrdili njihovu predanost obdržavanju židovskoga zakona. Predmeti su bili rimske izrade, što je bilo razvidno iz dizajna. Na drškama različitih predmeta (vrč, lopatica za ritualno kađenje) te na dnu brončane tave (patere) nalazili su se dekorativni oblici i likovi, od kojih su neki predstavljali junake grčkih mitova. Svako je lice bilo namjerno oštećeno tako što je uklonjen vrh nosa, a s nekih su predmeta lica bila potpuno sastrugana. Ti su brončani predmeti očito bili plijen koji su ustanici oteli Rimljanima, ali su ih potom obradili kako uporabom poganskih ukrasa ne bi kršili zakonsku zabranu štovanja likova. Yadin navodi talmudski naputak o skrnavljenju poganskih kumira, što je dio poslijebiblijskoga halahičkoga kodeksa, koji je primijenjen kod pronađenih predmeta kako bi ih Židovi mogli koristiti (Yadin, 1971, 102). ${ }^{40}$

U špilji je pronađen fragment svitka s dijelovima Psalma 15. i 16., koji odgovara masoretskomu tekstu (Yadin, 1971, 114; 1961a, 40). ${ }^{41}$ No najdragocjenije otkriće iznjedrio je sadržaj mješine za vodu od kozje kože pronađene, skupa s metalnim nožem i mjedenim zrcalom, u jedva primjetnom, uskom procjepu sasvim pri dnu lijevoga kraka špilje. U mješini su, uz nekoliko predmeta za kozmetiku poput bočice za miris, ukrasnih kamenčića, klupka neispredene obojane vune i vretena, pronađene četiri drvene pločice s tekstom i petnaest pisama, od kojih su neka bila izvanredno dobro očuvana. Nastala su vjerojatno 134. ili 135. (Yadin, 1961a, 50). U njima se Bar Kohba obraćao primateljima u prvom licu, s iznimkom pisama na grčkom, ali ni jedno nije vlastoručno potpisao. Pisma su pisana različitim rukopisom i potpisuju ih različiti pisari, što ukazuje na to da je Bar Kohba na raspolaganju imao administrativni tim. Sadržaj tih pisama omogućio je uvid u prilike tijekom zadnjega dijela ustanka, te djelomice u Bar Kohbinu osobnost kao odlučnoga lidera koji od podčinjenih pod prijetnjom kazne zahtijeva bespogovornu poslušnost. ${ }^{42}$

40 Usp. BT Avoda zara 53a, gdje je navedeno da se kumir može oskrnaviti odsijecanjem vrha uha, vrha nosa ili vrha prsta.

41 Iznimka je "pogrješka” u 3. retku Psalma 15 (Yadin piše 16).

42 Podrobniji sadržaj pisama u povijesnom kontekstu nalazi se u: Yadin, 1971, 124-139. 
Jezik većine pisama je aramejski, a neka su pisana hebrejskim i grčkim. Yadin navodi kako ne postoji očit razlog zašto su neka pisana aramejskim, a neka hebrejskim, te napominje kako su Židovi toga vremena dobro govorili oba jezika (Yadin, 1971, 124). ${ }^{43}$ Ime ustaničkoga vođe pojavljuje se na svim pismima, kao i na tekstu drvenih pločica. Samo na drvenoj podlozi uz ime je zapisana i njegova titula: Šimun Bar Kosiba, knez Izraela (ישראל שמעון בר כוסבה הנסי על) (Yadin, 1961a, 41). ${ }^{44}$ Yadin ukazuje na to kako je ime ustaničkoga vođe u pismima אוסבה katkad napisano (sa slovom o sameh), a katkad כושבה (sa slovom ש sin), ali ne nudi objašnjenje. Osim toga, u tekstu se nalaze »brojni nestandardno pisani dijelovi« (Wise, 2015, 253). Primjerice riječ šalom, koja se piše שלום, u pismu na drvenoj podlozi napisana je סלם, što je pravopisna pogrješka: predzadnje slovo (vav) može se ispustiti jer tvori samoglasnik $o$, ali se umjesto ש (šin $)^{45}$ ne može napisati o (sameh) jer se riječ više ne bi čitala šalom nego salom. Drugi je primjer pisanje prijedloga את, koji se i u modernom i u biblijskom hebrejskom piše odvojeno od imenice u nominativu i pretvara ju u akuzativ. U pismima umjesto תמקומות piše, što Yadin naziva »kolokvijalizmom«(Yadin, 1971, 181). ${ }^{46}$ Yadin smatra kako je izgledno da su Bar Kohbini pisari poznavali hebrejski, aramejski i grčki (Yadin, 1961a, 50). Nakon što su sredinom ožujka 1961. ponovno obavljena arheološka iskapanja, tijekom kojih su pronađena nova pisma što su završavala nekim oblikom nadnevka poput "prve godine Bar Kohbe", uporaba aramejskoga i hebrejskoga jezika postala je jasnija. Stariji su dokumenti pisani na aramejskom, a noviji na hebrejskom jeziku, pa Yadin pretpostavlja kako je Bar Kohba želio »obnoviti hebrejski kao službeni jezik države« (Yadin, 1971, 181). Nadalje, u jednom od pisama Rimljani se nazivaju רהומיה, i to je jedino poznato mjesto u kojem se za njih ne koristi riječ הגואים (ha-gojim, ovdje ha-goim), koja se javlja u svim drugim pismima (Yadin, 1961a, 46). Goji, mn. gojim, u ustaničkim je pismima napisana različito od njezina oblika u biblijskom tekstu גוי , גויים), a njezino je značenje "narodi" te se uglavnom ${ }^{47}$ koristi u smislu "nežidovi", odnosno "pogani”. Osim naslova נשיא ni u jednom od pronađenih pisama ne nalazi se izravna mesijanska titula; nigdje se Bar Kohbu ne oslovljava kao Mesiju. ${ }^{48}$

43 Yadin prenosi kako se Ben-Gurion, kad mu je pokazao prva otvorena pisma, a ona su bila napisana na aramejskom jeziku, obrecnuo: »Zašto su pisali aramejski, a ne hebrejski? «

44 Hebrejska riječ (nasi), koja je u pismu napisana s određenim članom ה, u modernom hebrejskom ima značenje "predsjednik", a tako ju Yadin prevodi u knjizi Bar-Kokhba.

45 Slovo šin se od slova sin razlikuje po tome što se iznad njegova desnoga kraka katkad, ali ne uvijek stavlja, točka.

46 Yadin također objašnjava kako takav način ukazuje na fonetsko pisanje, jer se riječ tako izgovara. Ništa slično ne može se naći u biblijskom hebrejskom. Akuzativ koji se nalazi već u prvoj rečenici Knjige Postanka glasi: בראשית ברא אלהים את השמים ואת הארץ.

47 U Post 12,2 Bog Abrahamu daje obećanje: »Velik ću narod [גרי ברימת od tebe učiniti.« U kasnijoj, rabinskoj literaturi, riječ goi poprima i pejorativno značenje.

48 To je jedan od razloga zbog kojih neki povjesničari osporavaju da su ga sljedbenici smatrali mesijom. To mišljenje opovrgava Bauckham tvrdnjom da Petrovo otkrivenje potvrđuje talmudski tekst prema kojem ga se zaista tako percipiralo (Bauckham, 1994, 36). Usp. BT Sanhedrin 93b. 
Judejska pisma predstavljaju gradivo od neprocjenjive vrijednosti za uvid u život judejskih židovskih zajednica iz vremena ustanka. Povjesničari su iz njih, između ostaloga, po prvi put saznali stvarno ime ustaničkoga vođe, imena sedmorice njemu podčinjenih vojnih zapovjednika, kao i postojanje upravitelja koji su se bavili civilnim poslovima poput opskrbe (Katz, 2006, 109-111). No pisma nisu pružila odgovore na ključna pitanja o ustanku pa »većina tema koje su bile nepoznate prije njihova pronalaska ostale su nepoznate i nakon njega« (Gichon, 1986, 15).

Među te teme spadaju tijek ratovanja, bitke i gubitci koje su obje strane trpjele, premda se iz epigrafskih i drugih arheoloških izvora može izvući nekoliko opreznih zaključaka. Kako je vidljivo iz Dionova izvještaja, rimske su se postrojbe u Judeji suočile s puno opasnijim neprijateljem nego što su očekivale i pretrpjele su bitne gubitke. Kako se brojnost i sposobnost rimske vojske u Judeji pokazivala nedostatnom za učinkovito potiskivanje ustanika, Hadrijan je onamo uputio čest cjelovitih legija (Druga, Treća, Šesta, Deseta, Dvanaesta i Trinaesta), te dijelove nekoliko drugih, tako da su u borbama u Judeji sudjelovali pripadnici čak deset ili jedanaest rimskih legija, a sveukupni broj rimskih vojnika prelazio je pedeset tisuća (Katz, 2006, 122-123). Dvanaesta legija Deiotariana u vrijeme ustanka posve je nestala (Avi-Yonah, 1976, 13), što upućuje na to da su ju uništili ustanici. ${ }^{49}$ Ozbiljnost ustanka bila je tolika da je Hadrijan, kako Dion navodi, iz Britanije onamo poslao jednoga od svojih ponajboljih vojskovođa Julija Severa, no postoje indikacije da ni to nije bilo dovoljno. Budući da su pronađeni rimski napisi u kojima se taj rat opisuje kao Expeditio Iudaica, a što je naslov koji se daje samo bitkama u kojima je sudjelovao car, moguće je da je Hadrijan osobno predvodio neke bitke (Katz, 2006, 124-125).

Posljednje ustaničko uporište bio je Beitar ${ }^{50}$ (ביתר), grad jugoistočno od Jeruzalema a sjeveroistočno od Betlehema, koji se danas na arapskom zove Kirbet el-Jahud, odnosno Židovska ruševina. Ako su ustanici i bili u Jeruzalemu, grad su napustili bez borbe, te su se sklonili u Beitar. Beitar je bio dobro utvrđen, na visini od 700 metara nadmorske visine s tri strane zaštićen klancima dubokima 150 metara, a s juga mu je prilaz otežan osamdesetmetarskim rovom dubine pet a širine petnaest metara (Yadin, 1971, 193; Mor, 2016, 215). O tijeku te posljednje bitke također se ne zna puno. Euzebije navodi da je opsada grada bila dugotrajna, sve dok glad i žeđ ustanike nije dovela »do krajnje točke pogibelji«, kao i da je ondje poginuo Bar Kohba (Euzebije, 2004, 376). Rimljani su, slično kao i kod opsade Masade, ustanike u utvrdi opkolili i izgradili opsadni zid, čiji su ostatci vidljivi i danas. Na tom su mjestu obavljena arheološka iskapanja kojima je 1984.

49 To je načelno općeprihvaćena pretpostavka (Gichon, 1986, 21-22; Mantel, 1968a, 237-239; Isaac i Roll, 1979, 61; Syme, 1988, 167), premda se Mor ni s time ne slaže (Mor, 2016, 351). Za suprotno mišljenje, tj. da je Deiotariana nestala/uništena prije pobune u Judeji usp. Mor, 1986; Keppie, 1973, 863.

50 Beitar se spominje u Jš 15,59 (u hrvatskom prijevodu: Beter). Ime toga grada, kao i ostalih deset gradova pobrojanih u istom retku, sačuvani su u grčkom prijevodu Jošue, ali ih u Hebrejskoj Bibliji nema (usp. Yadin, 1971, 193). 
potvrđeno da je današnji Kirbet el-Jahud doista Beitar. Arheolozi su ondje osim kamenih ostataka utvrde pronašli i ostatke oružja, koji su potvrdili da se na tom mjestu vodila bitka (Ginson, 2007, 161).

\section{Zaključak}

Drugi židovski ustanak pod vodstvom Bar Kohbe, usporedi li se s Prvim ustankom u kojem je slomljena židovska državnost i spaljen Hram, nije imao tako velike neposredne političke i vjerske posljedice. Njegovo gušenje, opet za razliku od Prvoga ustanka, nije nužno podrazumijevalo zadiranje u srž židovskoga identiteta. Još prije njegova izbijanja velik dio židovske zajednice prilagodio se životu bez hramskih obreda, a rabinsko je židovstvo već ušlo u razdoblje književne i interpretacijske kreativnosti, koja je obilježila susljedna stoljeća židovske povijesti. Vjersko središte već je otprije izmješteno ne samo iz Jeruzalema, nego i općenito iz Judeje, odnosno iz Javnea, i nalazilo se je u Galileji kako prije tako i poslije Bar Kohbina ustanka. Ali je neposredna posljedica ustanka bilo nezapamćeno razaranje Judeje i početak onoga što se je kasnije pokazalo najduljim izgnanstvom židovskoga naroda iz svoje zemlje. Zbog svega toga, pa i usprkos prvorazrednim recentnim arheološkim otkrićima, dvojbi vezanih za ustanak je mnogo. Kronologije ili nisu pisane ili nisu sačuvane. Među dvojbama su i neke koje se odnose na temeljne podatke poput »neposrednih uzroka, tijeka i zemljopisnoga opsega Bar Kohbina rata « (Bowman et al., 2007, 671-672), kao i mogućega osvajanja Jeruzalema.

Dugoročne pak posljedice ustanka, poglavito u pitanjima eshatologije, odnosno razvoja krajnje opreznoga pristupa mesijanskim očekivanjima i odbacivanja aktivističkoga mesijanizma, bile su goleme, što je osobito došlo do izražaja u kontekstu obnavljanja židovske državnosti (Havel, 2013, 261). Stoga se u 20. stoljeću pojavilo zanimanje za Drugi ustanak ne samo kao za događaj relevantan za drevnu židovsku povijest, nego i za neke od najvažnijih suvremenih židovskih tema, jer je tradicionalni odnos između vjere i politike u židovstvu uvelike oblikovan pod utjecajem iskustva Drugoga ustanka. Obnova židovske državnosti u Erec Izraelu nije samo potaknula propitivanje uvriježenih shvaćanja Bar Kohbe, nego je i omogućila istraživanja ustanka donedavno gotovo nezamisliva iz razloga koji se kreću od političkih i vjerskih, do znanstvenih i tehnoloških.

\section{Literatura:}

Abramsky, Samuel (2007). Bar Kokhba. U: Fred Skolnik (ur.), Encyclopaedia Judaica: Volume 3: Ba-Blo (str. 156-161). Detroit: Thomson Gale.

Apostolski oci II. (2010). Apostolski oci II.: Didaché: Klement Rimski: Pismo Korinćanima. Barnabina poslanica. Split: Verbum.

Avi-Yonah, Michael (1976). The Jews of Palestine: A Political History from the Bar Kokhba War to the Arab Conquest. Oxford: Basil Blackwell.

Avi-Yonah, Michael et al. (ur.) (2006). Jerusalem: The Saga of the Holy City. Delray Beach: Levenger Press. 
Bauckham, Richard (1994). The Apocalypse of Peter: A Jewish Christian Apocalypse from the Time of Bar Kokhba. Apocrypha, 5, 7-111.

Bauckham, Richard (2007). James and the Jerusalem Community. U: Oskar Skarsaune i Reidar Hvalvik (ur.), Jewish Believers in Jesus: The Early Centuries (str. 55-95). Peabody: Hendrickson Publishers.

Biblija. Jure Kaštelan i Bonaventura Duda (ur.), Biblija: Stari i Novi zavjet. Zagreb: Kršćanska sadašnjost, 1995.

Bowman, Alan K.; Garnsey, Peter; Rathbone, Dominic (ur.) (2007). The Cambridge Ancient History: The High Empire, A.D. 70-192 (Second Edition ed. Vol. XI). Cambridge: Cambridge Univeristy Press.

BT Avoda zara. U:Sefaria.URL: https://www.sefaria.org/Avodah_Zarah?lang=bi (26.09.2019.)

BT Sanhedrin 93b. U: Sefaria. URL: https://www.sefaria.org/Sanhedrin?lang=bi (26.09.2019.)

BT Ta'anit. U: Sefaria. URL: https://www.sefaria.org/Taanit?lang=bi (26.09.2019.)

Da-Don, Kotel (2004). Židovstvo: Život, teologija i filozofija. Zagreb: Profil.

Dion, Kasije (1925). Dio's Roman History with an English Translation by Earnest Cary, Ph.D.: VIII. London: William Heinemann.

Eldad, Israel (2007). The Jewish Revolution: Jewish Statehood. Jerusalem: Gefen.

Elliot, J. K. (2005). The Apocryphal New Testament. Oxford: Oxford University.

Epiphanius (1935). Treatise on Weights and Measures: The Syriac Version edited by James Elmer Dean. Chicago: University of Chicago.

Euzebije Cezarejski (2004). Crkvena povijest. Split: Služba Božja.

Frankel, Jonathan (ur.) (1991). Jews and Messianism in the Modern Era: Metaphor and Meaning. Oxford: Oxford University Press.

Gibson, Shimon (2007). New Archaeological Finds. U: Fred Skolnik (ur.), Encyclopaedia Judaica: Volume 3: Ba-Blo (str. 161-162). Detroit: Thomson Gale.

Gichon, Mordechai (1986). New Insight into the Bar Kokhba War and a Reappraisal of Dio Cassius 69.12-13. The Jewish Quarterly Review, 77(1), 15-43.

Goold, E. P. (ur.) (1921, 1991). Scriptores Historiae Augustae with an English translation (Vol. I). Cambridge, Massachusetts: Harvard University Press.

Havel, Boris (2013). Arapsko-izraelski sukob: Religija, politika i povijest Svete zemlje. Zagreb: Naklada Ljevak.

Havel, Boris; Kasapović, Mirjana (2016). Napomene o transkripciji i transliteraciji. U: Mirjana Kasapović (ur.), Bliski istok: Politika i povijest (str. xii-xxii). Zagreb: Fakultet političkih znanosti.

Isaac, Benjamin; Roll, Israël (1979). Judaea in the Early Years of Hadrian's Reign. Latomus, 38(1), 54-66.

Jeronim (1906). Jerome's Apology in Answer to Rufinus. U: Henry Wace i Philip Schaff (ur.), A Select Library of Nicene and Post-Nicene Fathers of the Christian Church: Volume III (str. 518-541). New York: The Christian Literature Company.

Jeronim (2005). Jerome, Chronicle (2005) pp.188-332. Latinski URL: http://www.tertullian.org/fathers/jerome_chronicle_06_latin_part2.htm; engleski URL http://www. tertullian.org/fathers/jerome_chronicle_03_part2.htm (08.09.2019.)

JT Ta'anit. U: Sefaria. URL: https://www.sefaria.org/Jerusalem_Talmud_Ta'anit?lang=bi (26.09.2019.)

Justin (2012). Apologije. Split: Verbum.

Katz, Steven T. (ur.) (2006). The Cambridge History of Judaism: Volume 4: The Late Roman-Rabbinic Period. New York: Cambridge University Press. 
Keppie, Lawrence J. F. (1973). The Legionary Garrison of Judaea under Hadrian. Latomus, 32(4), 859-864.

Kersel, Morag M.; Kletter, Raz (2006). Heritage for Sale? A Case Study from Israel. Journal of Field Archaeology, 31(3), 317-327.

Mantel, Hugo (1968a). The Causes of the Bar Kokba Revolt. The Jewish Quarterly Review, 58(3), 224-242.

Mantel, Hugo (1968b). The Causes of the Bar Kokba Revolt (Continued). The Jewish Quarterly Review, 58(4), 274-296.

Mantel, Hugo (1969). The Causes of the Bar Kokba Revolt: Postscript. The Jewish Quarterly Review, 59(4), 341-342.

Meshorer, Ya'akov (1982). Ancient Jewish Coinage Vol. II: Herod the Great through Bar Cochba. New York: Amphora Books.

Mor, Menachem. (1986). Two Legions: The Same Fate? The Disappearance of the Legions IX Hispana and XXII Deiotariana. Zeitschrift für Papyrologie und Epigraphik, 62, 267-278.

Mor, Menahem (2016). The Second Jewish Revolt: The Bar Kokhba War, 132-136 CE. Leiden: Brill.

Paget, J. N. B. Carleton (1991). Barnabas 9:4: A Peculiar Verse on Circumcision. Vigiliae Christianae, 45(3), 242-254.

Schaff, Philip; Wace, Henry (ur.) (1906). A Selected Library of Nicene and Post-Nicene Fathers of the Christian Church, Second Series: Volume 3. New York: The Christian Literature Company.

Schürer, Emil (1973). The History of the Jewish People in the Age of Jesus Christ, Volume I: A New English Version Revised and Edited by Geza Vermes \& Fergus Millar. Edinburgh: T. \& T. Clark Ltd.

Severus, Sulpitius (1890-1900). The Works of Sulpitius Severus. New York: Christian Literature Company.

Skarsaune, Oskar (1987). The Proof from Prophecy: A Study in Justin Martyr's Proof Text Tradition Text-Type, Provenance, Theological Profile. Leiden: E. J. Brill.

Skarsaune, Oskar (2002). In the Shadow of the Temple: Jewish Influence on Early Christianity. Downers Grove, Illinois: InterVarsity Press.

Skarsaune, Oskar (2007). Jewish Christian Sources Used by Justin Martyr and Some Other Greek and Latin Fathers. U: Oskar Skarsaune i Reidar Hvalvik (ur.), Jewish Believers in Jesus: The Early Centuries (str. 380-416). Peabody: Hendrickson Publishers.

Skarsaune, Oskar; Hvalvik, Reidar (ur.) (2007). Jewish Believers in Jesus: The Early Centuries. Peabody: Hendrickson Publishers.

Smallwood, Mary E. (1959). The Legislation of Hadrian and Antoninus Pius against Circumcision. Latomus, 18(2), 334-347.

Smallwood, Mary E. (1961). The Legislation of Hadrian and Antoninus Pius against Circumcision: Addendum. Latomus, 20(1), 93-96.

Smallwood, Mary E. (2001). The Jews Under Roman Rule: From Pompey to Diocletian: A Study in Political Relations. Leiden: Brill.

Syme, Ronald (1988). Journeys of Hadrian. Zeitschrift für Papyrologie und Epigraphik, 73, 159-170.

Watson, Alan (ur.) (1998). The Digest of Justinian: Volume 4. Revised ed. Philadelphia: University of Pennsylvania Press.

Wise, Michael Owen (2015). Language and Literacy in Roman Judaea: A Study of the Bar Kokhba Documents. London: Yale University Press. 
Yadin, Yigael (1961a). Expedition D. Israel Exploration Journal, 11(1-2), 36-52.

Yadin, Yigael (1961b). More on the Letters of Bar Kochba. The Biblical Archaeologist, 24(3), 86-95.

Yadin, Yigael (1966). Masada: Herod's Fortress and the Zealots' Last Stand. New York: Welcome Rain.

Yadin, Yigael (1971). Bar-Kokhba: The Rediscovery of the Legendary Hero of the Second Jewish Revolt against Rome. Tel Aviv: Japhet Press.

Yadin, Yigael (ur.) (1976). Jerusalem Revealed: Archaeology in the Holy City 1968-1974. Jerusalem: Yale University Press.

Bar Kohba and the Second Jewish Revolt

Historical Sources: Roman, Jewish, Christian and Archeological

Boris Havel*

\section{Summary}

Many aspects of the Second Jewish Revolt against the Romans (132-135) has been an enigma to historians since becoming an object of scholarly research. Causes of the rebellion, the course of the war, the military performance of both the rebels and the Romans and the expanse of territory affected by the revolt are still debatable. Unlike with the First Revolt (66-73), there are no comprehensive sources on the Second Revolt that are suitable for study, but rather only scattered textual fragments in which the Revolt is addressed only in passing. Since the 1950's, archeologists have found new evidence revealing more details about the Revolt, the most important of which was probably the real name of its leader. However, many fragments are still missing for a reconstruction of the course of events, often considered crucial in shaping Jewish Messianism in the following centuries and for the perception of contemporary Jewish statehood within the religious community.

Key words: Bar Kohba, Judaea, Christians, Jews, Messiah, Hadrian, Roman Empire

* Boris Havel, Ph.D., Assistant Professor, Faculty of Political Science, University of Zagreb. Address: Lepušićeva 6, 10000 Zagreb, Croatia.E-mail: boris.havel@fpzg.hr 